\title{
Effect of Body Mass Index on Global DNA Methylation in Healthy Korean Women
}

\author{
Yeon Kyung $\mathrm{Na}^{1}$, Hae Sook Hong ${ }^{1}$, Duk Hee Lee ${ }^{2}$, Won Kee Lee ${ }^{2}$, and Dong Sun Kim*
}

\begin{abstract}
Obesity is known to be strongly associated with cardiovascular disease and cancer, the leading causes of mortality worldwide, and develops owing to interactions between genes and the environment. DNA methylation can act as a downstream effector of environmental signals, and analysis of this process therefore holds substantial promise for identifying mechanisms through which genetic and environmental factors jointly contribute to disease risk. Global DNA methylation of peripheral blood cells has recently been proposed as a potential biomarker for disease risk. Repetitive element DNA methylation has been shown to be associated with prominent obesity-related chronic diseases, but little is known about its relationship with weight status. In this study, we quantified the methylation of Alu elements in the peripheral blood DNA of 244 healthy women with a range of body mass indexes (BMls) using pyrosequencing technology. Among the study participants, certain clinical laboratory parameters, including hemoglobin, serum glutamic oxaloacetic transaminase, serum glutamic-pyruvic transaminase, total cholesterol, and triglyceride levels were found to be strongly associated with BMI. Moreover, a U-shaped association between BMI and Alu methylation was observed, with the lowest methylation levels occurring at BMls of between 23 and $30 \mathrm{~kg} / \mathrm{m}^{2}$. However, there was no significant association between Alu methylation and age, smoking status, or alcohol consumption. Overall, we identified a differential influence of BMI on global DNA methylation in healthy Korean women, indicating that BMI-related changes in Alu methylation might play a complex role in the etiology and pathogenesis of obesity. Further studies are required to elucidate the mechanisms underlying this relationship.
\end{abstract}

Department of Anatomy and Brain Korea 21 Plus KNU Biomedical Convergence Program, ${ }^{1}$ College of Nursing, ${ }^{2}$ Department of Preventive Medicine, School of Medicine, Kyungpook National University, Daegu 702-422, Korea

*Correspondence: doskim@knu.ac.kr

Received 27 March, 2014; revised 21 May, 2014; accepted 26 May, 2014; published online 13 June, 2014

Keywords: Alu, BMI, methylation, pyrosequencing, U-shape

\section{INTRODUCTION}

DNA methylation is a core epigenetic process that influences a wide variety of biological mechanisms, including gene expression, chromosomal stability, imprinting, and cellular differentiation (Bernstein et al., 2007). Methylation can mediate environmental influences on gene expression and can modulate disease risk associated with genetic variation (Foley et al., 2009). Abnormal DNA methylation patterns (including genome-wide hypomethylation and gene-specific hypo- and hypermethylation) have been shown to be associated with a range of health outcomes (Ozanne and Constancia, 2007). In cancer and certain other diseases, most of these changes have been observed at the tissue level (Esteller et al., 2001; Rodenhister and Mann, 2006). Data relating to whether DNA methylation changes in peripheral blood cells can serve as useful, informative biomarkers for different health outcomes is much more limited, but new information is rapidly emerging (Heyn and Esteller, 2012). A number of methods are available for the analysis of global DNA methylation levels [total content of 5-methylcytosine (5-mC)] (Terry et al., 2011). There are over 500,000 long-interspersed nuclear elements (LINEs) and 1,500,000 short-interspersed nuclear elements (SINEs) across the human genome. Alu elements are the most common SINE; comprising $11 \%$ the human genome and containing a third of all methylation sites (Deininger and Batzer, 1999). The substantial representation of these repetitive elements throughout the genome makes their effectiveness as proxies for global DNA methylation highly evident. Indeed, methylation levels in Alu and LINE-1 repeats have been shown in previous studies to be associated with total genomic methylation content (Weisenberger et al., 2005; Yang et al., 2004). Estimates of these are increasingly being used in epidemiological investigations owing to their relatively low-cost, high-throughput, and the fact that they can offer quantitative results (Weisenberger et al., 2005). Interestingly, global methylation measures in blood DNA have been shown to vary in relation to demographic and lifestyle characteristics, including age, sex, smoking status, alcohol consumption, physical activity, and diet (Heyn and Esteller, 2012; Zhu et al., 2012). However, there are still few studies of the relationship between DNA methylation and weight status.

Obesity is simply defined as a condition of abnormal or excessive fat accumulation in adipose tissue, to the extent that health may be impaired. Obesity is the result of the interplay between external (environmental) and internal (genetic) factors. 
It has been cited as the epidemic of our time, with obesity rates sharply and steadily rising in many parts of the world, leading to increased morbidity and mortality due to type 2 diabetes and cardiovascular disease (Danaei et al., 2009). Obesity-related mortality by far exceeds mortality caused by other common diseases (Anderson and Caswell, 2009). Moreover, about 20\% of all cancers are caused by overweight, and obesity has been shown to be associated with increased risk and worse outcomes following diagnosis (Wolin et al., 2010). Furthermore, the incidence of some types of cancer have been shown to be strongly associated with body mass index (BMI), which has historically been used to define obesity (Renehan et al., 2008). Our understanding of how and why obesity develops is incomplete. To date, several studies concerning DNA methylation and obesity have focused primarily on gene-specific methylation and had relatively small sample sizes (Carless et al., 2013; Feinberg et al., 2010; Fujiki et al., 2009; Milagro et al., 2012; Wang et al., 2010). Currently, studies of global methylation levels in blood DNA and BMI have yielded inconsistent results (Kim et al., 2009; Perng et al., 2013; Piyathilake et al., 2011; Wang et al., 2010; Zhang et al., 2011a;2011b; Zhu et al., 2012). $\mathrm{BMI}$ is now considered to be an important determinant of methylation biomarkers in the blood of women of reproductive age (van Driel et al., 2009). Interestingly, recent evidence has shown that alterations in global DNA methylation may be an important contributor to incidence risk of cancer and cardiovascular disease (Baccarelli et al., 2010; Terry et al., 2011). In this study, in order to investigate the specific effects of BMl on global DNA methylation and develop blood-based biomarker as initial screening test for obesity-related disease, we quantified the methylation of Alu elements in the peripheral blood DNA of 244 women with a range of BMls using pyrosequencing technology.

\section{MATERIALS AND METHODS}

\section{Study population}

Study subjects were 244 apparently healthy women aged between 20 and 51 years (mean $32 \pm 7.9$ years). This study was approved by the Institutional Review Board of Kyungpook National University Hospital. Additionally, informed written consent was obtained from all subjects before they participated in the study. Demographic information and lifestyle factors were determined for all participants by trained interviewers using a standardized questionnaire via face-to-face interviews. Height and bodyweight were measured using standard methods with participants wearing light clothes. BMI is easy to obtain [calculated by weight divided by height squared $\left(\mathrm{kg} / \mathrm{m}^{2}\right)$ ] and is considered to be an acceptable proxy for under and overweight. $\mathrm{BMI}$ has also been shown to be directly related to health risks and mortality in many populations. According to the current international standard (WHO 1998), a BMI of over $25 \mathrm{~kg} / \mathrm{m}^{2}$ is considered to indicate overweight and a BMl of over and 30 $\mathrm{kg} / \mathrm{m}^{2}$ is considered to indicate obesity. However, the BMl cutoff values for overweight and obesity vary in Asian populations from 22 to $25 \mathrm{~kg} / \mathrm{m}^{2}$ and the increased risk of co-morbidities conferred by obesity have been shown to occur at a lower BMI in several Asian populations (Low et al., 2009). We therefore divided the participants into 3 categories based on BMI normal weight $\left(\mathrm{BMl}<23 \mathrm{~kg} / \mathrm{m}^{2}\right)$, overweight $\left(23 \mathrm{~kg} / \mathrm{m}^{2} \leq \mathrm{BMl}<30\right.$ $\mathrm{kg} / \mathrm{m}^{2}$ ), and obese $\left(\mathrm{BMI} \geq 30 \mathrm{~kg} / \mathrm{m}^{2}\right.$ ). Blood samples were obtained via venipuncture after overnight fasting, and serum samples were separated by centrifugation and transferred to uncontaminated bottles with Teflon-coated caps. All samples were kept frozen at $-70^{\circ} \mathrm{C}$ until analyses were conducted. Clinical laboratory values were determined by standard biochemical automatic or semi-automatic methods.

\section{Blood DNA extraction and bisulfite treatment}

Genomic DNA was extracted from whole-blood samples using a QIAamp DNA Blood Kit (Qiagen, USA). One microgram DNA was bisulfite-modified using an EZ DNA Methylation-Gold Kit (Zymo Research, USA) according to the manufacturer's instructions. Final elution was performed with $30 \mu \mathrm{l}$ M-Elution Buffer (Zymo Research) and was stored at $-70^{\circ} \mathrm{C}$ until analyzed Built-in analysis of non-CpG cytosine residues provided an internal control for the completeness of bisulfate treatment. Following treatment with bisulfite, the conversion of this $\mathrm{C}$ into $\mathrm{T}$ is expected to be $100 \%$. It is possible to insert a $\mathrm{C} / \mathrm{T}$ singlenucleotide polymorphism into the sequence to be analyzed, and this will result in $100 \%$ Ts if conversion is efficient.

\section{Assay of Alu methylation}

Alu methylation analysis was quantitatively performed on the bisulfite-treated DNA using pyrosequencing with the polymerase chain reaction (PCR) primers and conditions previously described (Bollati et al., 2007). In brief, the bisulfite-treated samples (50 ng) were amplified with a biotin-labeled primer via PCR, which enables the conversion of the PCR product to a single-stranded DNA template suitable for pyrosequencing. Confirmation of the quality of the PCR products and their freedom from contamination was established on $2 \%$ agarose gels with ethidium bromide staining. After purification of PCR products using Sepharose beads on PyroMark Vacuum Prep Workstation (Qiagen), pyrosequencing was carried out using the PyroMark Q96MD System (Qiagen) according to manufacturer's instructions, including a single-strand binding protein. The percentage of methylatation was expressed for each DNA locus as $\% 5-\mathrm{mC}$ divided by the sum of methylated and unmethylated cytosines. We tested each marker 3 times and used the average percentage in the statistical analysis. Three controls were included in every pyrosequencing run. One well was filled with water to ensure no contamination, and 2 wells were filled with CpGenome Universal methylated and unmethylated DNA (Chemicon, USA) to evaluate the repeatability of the assay.

\section{Statistical analysis}

Statistical analysis and plotting was performed using $\mathrm{R}$ version 2.15.3 (http://www.r-project.org). Continuous variables were compared using one-way analysis of variance or analysis of covariance and pairwise post hoc comparison identified statistical differences following Bonferroni adjustment. Categorical variables were compared using a chi-squared test.

\section{RESULTS AND DISCUSSION}

Growing evidence indicates that there are sex differences in global DNA methylation in the blood (Terry et al., 2011; Zhu et al., 2012). We have chosen healthy women as study subjects. First, overweight and obesity pose more serious health challenge to women than men. Obesity is a common disorder affecting approximately 1 in 3 women and the prevalence of extreme obesity is about $50 \%$ higher among women than men (Ryan and Braverman-Panza, 2014). Moreover, prevalence of metabolic syndrome is associated with obesity and its escalation has been steeper in women, particularly in young women (Regitz-Zagrosek et al., 2007). Second, recent result has shown 
Table 1. Characteristics of study participants

\begin{tabular}{|c|c|c|c|c|c|c|}
\hline & $\begin{array}{l}\text { Normal weight } \\
\quad(n=92)\end{array}$ & $\begin{array}{l}\text { Overweight } \\
(n=79)\end{array}$ & $\begin{array}{l}\text { Obese } \\
(n=73)\end{array}$ & $F / X^{2}$ & P-value & $\begin{array}{l}\text { Post hoc compar- } \\
\text { ison using the } \\
\text { Duncan method }\end{array}$ \\
\hline Age, years (SD) & $31.52(8.84)$ & $31.70(5.52)$ & $32.93(8.98)$ & 0.72 & 0.487 & \\
\hline $\begin{array}{l}\text { Smoking status, } \mathrm{n}(\%) \\
\text { Non-smoker } \\
\text { Former smoker } \\
\text { Current smoker }\end{array}$ & $\begin{array}{c}67(72.8) \\
6(6.5) \\
19(20.7)\end{array}$ & $\begin{array}{c}60(75.9) \\
6(7.6) \\
13(16.5)\end{array}$ & $\begin{aligned} 52 & (71.2) \\
2 & (2.7) \\
19 & (26.1)\end{aligned}$ & 3.51 & 0.477 & \\
\hline $\begin{array}{l}\text { Alcohol consumption, n (\%) } \\
\text { Non-drinker } \\
\text { Ever drinker }\end{array}$ & $\begin{array}{l}22(23.9) \\
70(76.1)\end{array}$ & $\begin{array}{l}23(29.1) \\
56(70.9)\end{array}$ & $\begin{array}{l}30(41.1) \\
43(58.9)\end{array}$ & 7.58 & 0.270 & \\
\hline $\begin{array}{l}\text { Hemoglobin, \% (SD) } \\
\text { Creatinine, mg/dl (SD) } \\
\text { Glucose, mg/dl (SD) } \\
\text { GOT, units/l (SD) }\end{array}$ & $\begin{array}{l}11.97(1.05) \\
0.87(0.12) \\
93.72(6.17) \\
17.50(4.48)\end{array}$ & $\begin{array}{c}12.23(0.99) \\
0.86(0.09) \\
95.57(23.19) \\
19.67(7.17)\end{array}$ & $\begin{array}{c}12.57(1.22) \\
0.87(0.10) \\
93.18(14.18) \\
24.27(16.43)\end{array}$ & $\begin{array}{l}6.18 \\
0.53 \\
0.49 \\
9.08\end{array}$ & $\begin{array}{c}0.002 \\
0.587 \\
0.611 \\
<0.001\end{array}$ & $3>2,1$ \\
\hline $\begin{array}{l}\text { GPT, units/l (SD) } \\
\text { Total bilirubin, mg/dl (SD) }\end{array}$ & $\begin{array}{c}13.36(8.08) \\
0.62(0.26)\end{array}$ & $\begin{array}{c}18.48(12.58) \\
0.59(0.30)\end{array}$ & $\begin{array}{c}29.92(27.62) \\
0.58(0.27)\end{array}$ & $\begin{array}{c}18.80 \\
0.71\end{array}$ & $\begin{array}{c}<0.001 \\
0.492\end{array}$ & $3>2,1$ \\
\hline $\begin{array}{l}\text { Total cholesterol, mg/dl (SD) } \\
\text { Triglyceride, mg/dl (SD) }\end{array}$ & $\begin{array}{l}179.59(31.66) \\
83.93(46.07)\end{array}$ & $\begin{array}{l}190.94(47.89) \\
116.57(86.88)\end{array}$ & $\begin{array}{c}199.08(30.35) \\
168.48(128.18)\end{array}$ & $\begin{array}{c}5.68 \\
17.92\end{array}$ & $\begin{array}{l}0.004 \\
<0.001\end{array}$ & $\begin{array}{c}3>2>1 \\
3>2 \geq 1\end{array}$ \\
\hline
\end{tabular}

SD, standard deviation; GOT, glutamic oxaloacetic transaminase; GPT, glutamic pyruvic transaminase
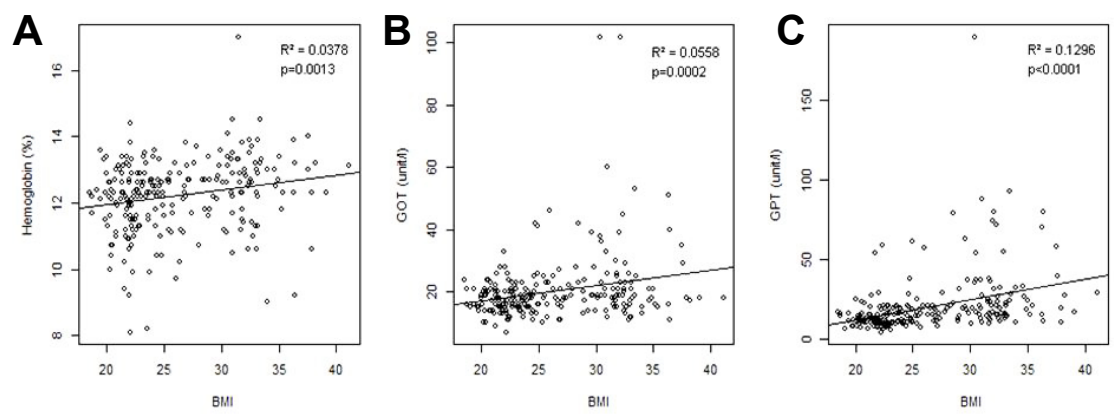

Fig. 1. Scatter plot and simple regression of population characteristics and body mass indexes (BMls). (A) hemoglobin, (B) serum glutamic oxaloacetic transaminase (GOT), (C) serum glutamic pyruvic transaminase (GPT), (D) total cholesterol, (E) triglyceride levels.
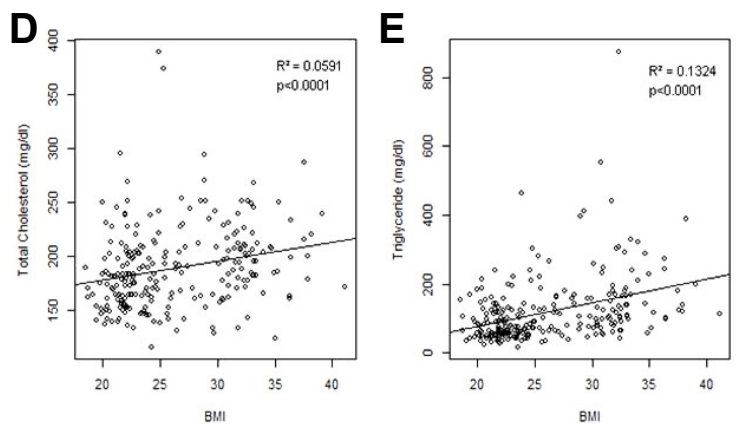

that $\mathrm{BMI}$ is a strong determinant of methylation biomarkers in women of child-bearing age (van Driel et al., 2009), indicating a greater likelihood of BMI effects on global DNA methylation in women. Finally, previous studies investigating the effect of BMI on global DNA methylation include mainly male populations (Zhu et al., 2012). In addition, we have found that Alu assays may be a more sensitive method for detecting global DNA hypomethylation in peripheral blood leukocytes in the general population than LINE-1 assays (Kim et al., 2009). Most studies have focused primarily on LINE-1 methylation as a surrogate for global DNA methylation (Perng et al., 2013; Piyathilake et al., 2011; Zhang et al., 2011a; 2011b). In this study, we determined

Alu methylation levels in a population of Korean women. The characteristics of the study population are shown in Table 1. Obese participants had higher baseline hemoglobin, serum glutamic-oxaloacetic transaminase (GOT), serum glutamicpyruvic transaminase (GPT), total cholesterol (TC), and triglyceride (TG) levels than normal weight and overweight participants. Scatter plot and linear regression analyses showed that these biochemical parameters were positively correlated with $\mathrm{BMI}$ (Fig. 1), which is consistent with recent observations that GOT and GPT levels are strongly associated with BMI, TC, and TG in Asian populations (Lin et al., 2010; Sull et al., 2009). 
BMI-Associated Global DNA Methylation Change

Yeon Kyung $\mathrm{Na}$ et al.

Table 2. Correlation between Alu methylation and BMI

\begin{tabular}{|c|c|c|c|c|c|c|}
\hline \multirow{2}{*}{ Gene } & \multicolumn{3}{|c|}{ Crude means } & \multicolumn{3}{|c|}{ Adjusted means* } \\
\hline & Mean & $\mathrm{F}$ & $\mathrm{P}$-value & Mean & $\mathrm{F}$ & $\mathrm{P}$-value \\
\hline \multicolumn{7}{|l|}{ Alu methylation } \\
\hline Normal weight & $26.27 \pm 0.82$ & 67.46 & $<0.001$ & $26.28 \pm 0.09$ & 67.72 & $<0.001$ \\
\hline Overweight & $24.96 \pm 0.45$ & & & $24.95 \pm 0.12$ & & \\
\hline Obese & $25.99 \pm 0.94$ & & & $25.96 \pm 0.10$ & & \\
\hline
\end{tabular}

${ }^{*}$ Adjusted for clinical laboratory values including hemoglobin, serum glutamic oxaloacetic transaminase, serum glutamic pyruvic transaminase, total cholesterol, and triglyceride levels. The Bonferroni method was used for post-comparison.
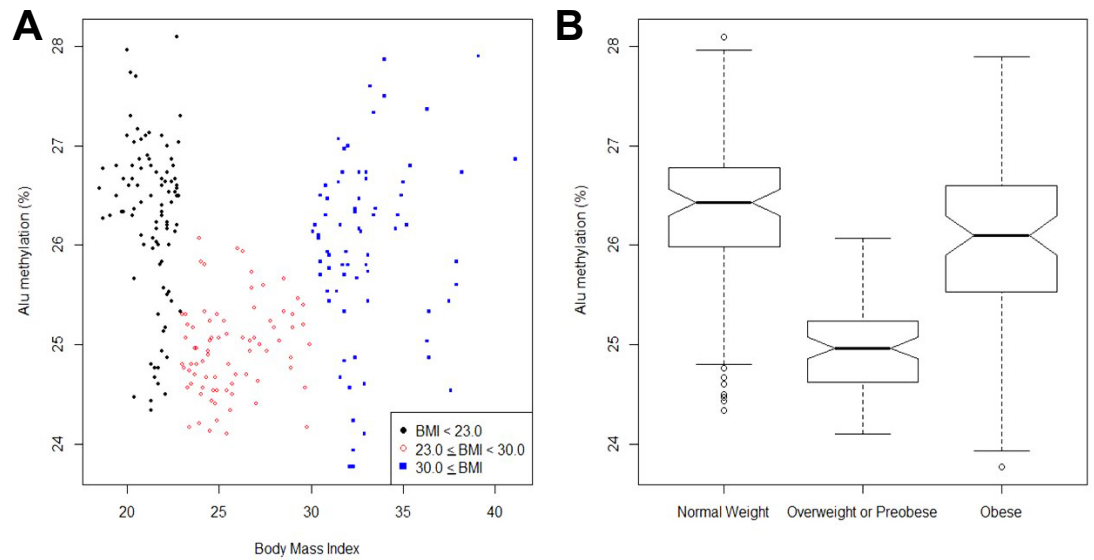

Fig. 2. Graphic representation of body mass index (BMI)-related global DNA methylation. (A) Scatter plot of BMl and Alu methylation, (B) Percentage of Alu methylation of blood cells in normal weight, overweight/pre-obese, and obese subjects.
Taken together, our data support the hypothesis that bodyweight may be the major factor in determining serum liver enzyme levels. Moreover, a significantly lower level of Alu methylation was found in overweight participants compared with normal weight or obese participants $(p<0.0001)$, but no significant difference was observed between the latter 2 groups, indicating a U-shaped association between Alu methylation and BMI (Table 2 and Fig. 2). After adjusting for other clinical covariates, this association was still found to be significant (Table 2). However, age, smoking status, and alcohol consumption were not significantly associated with Alu methylation levels in blood cells (data not shown). Similarly, previous studies have reported no association between smoking, alcohol consumption, and leukocyte DNA methylation (Hsiung et al., 2007; Kim et al., 2009; Terry et al., 2011; Zhu et al., 2012).

To date, studies of global methylation levels of blood DNA and BMI have yielded inconsistent results (Kim et al., 2009; Perng et al., 2013; Piyathilake et al., 2011; Wang et al., 2010; Zhang et al., 2011a; 2011b; Zhu et al., 2012). Most previous studies reported no significant association between BMI and global DNA methylation (Kim et al., 2009; Wang et al., 2010; Zhang et al., 2011a; 2011b; Zhu et al., 2012). In contrast, higher BMI has been reported to be associated with lower LINE-1 methylation (Perng et al., 2013; Piyathilake et al., 2011). Notably, we observed that participants with a BMI of 25 to $30 \mathrm{~kg} / \mathrm{m}^{2}$ had the lowest methylation levels compared with the other groups, and that Alu methylation was elevated among those with a BMI higher or lower than that range. To the best of our knowledge, this is the first study to report a novel U-shaped association between BMI and Alu methylation. Interestingly, the association between $\mathrm{BMI}$ and all-cause mortality has previously been shown to be $U$-shaped, with the concave region corresponding to BMls of between 22 and $26 \mathrm{~kg} / \mathrm{m}^{2}$ (Berrington de
Gonzalez et al., 2010; Whitlock et al., 2009; Zheng et al., 2011). Recently, we have observed that persistent organic pollutants, polychlorinated biphenyls are related to MGMT hypermethylation with an inverted $U$-shaped curve ( $P$ for quadratic term < $0.01)$. The prevalence of hypermethylation was highest in the subjects in the $2^{\text {nd }}$ quintile (28.4\%); however the subjects in the $5^{\text {th }}$ quintile had a low prevalence of hypermethylation $(8.2 \%)$ (unpublished data). Taken together, these data suggest the biphasic (hermetic) dose response model in which adaptive responses to low doses otherwise harmful conditions improve the functional ability of the cells and organism, resulting in a $U$ or inverted U-shaped dose response (Calabrese, 2010). Accordingly, several lines of evidence are presented that DNA methylation may be an attractive candidate molecular mechanism for hormesis-like response (Vaiserman, 2011).

Although the exact mechanism underlying the elevated Alu methylation observed in the blood cells of obese people is not known, several possible explanations have been suggested. First, it is reasonable to speculate that sleeping disturbance might contribute to increases in Alu methylation in obese people. Obstructive sleep apnea (OSA) is highly prevalent among obese patients (Young et al., 1993) and methylation of the endothelial nitric oxide synthase and forkhead box P3 genes in blood DNA has been shown to be linearly associated with the severity of OSA (Kheirandish-Gozal et al., 2013; Kim et al., 2012). This suggests that global methylation can be influenced by OSA and other sleep disorders. In support of this theory, we found that scored sleep management was higher in normal and overweight subjects compared with obese ones (data not known), indicating that obese individuals may have poorer sleep quality than non-obese people. Second, although BMI does not differentiate between muscle mass and adipose tissue, people with high BMI can be inferred to have high levels of 
body fat, causing higher levels of inflammatory markers such as interleukin (IL)-6 (Ramkumar et al., 2004). Moreover, persistent inflammation may cause global DNA hypermethylation in peripheral blood cells via IL-6 signaling (Stenvinkel et al., 2007). Thus, it is likely that elevated Alu methylation in people with high BMI is a consequence of a low but continuous inflammatory drive of obesity. Third, Kamei et al. (2010) demonstrated that the expression of DNA methyltransferase $3 a$ is markedly upregulated in the adipose tissue of obese mice. Similarly, a significantly higher frequency of RASSF1A, p16 and $h M L H 1$ methylation is observed in nonmalignant tissues of obese patients (Peters et al., 2007; Ye et al., 2006). In light of evidence that tissue-specific methylation profiles are reflected in circulating cell epigenomics (Yang et al., 2010), it is tempting to speculate that obesity can increase global methylation levels in peripheral blood DNA. Fourth, there is compelling evidence that heterogeneity in the number of specific leukocytes has the potential to confound methylation measurements using whole blood DNA and that increased total leukocytes are associated with obesity (Talens et al., 2010; Veronelli et al., 2004). Thus, a plausible hypothesis is that a progressively uprising trend at high BMI might be due to differential lymphocyte counts associated with adiposity development. In this respect, it is noteworthy that DNA methylation is closely related to lymphocyte count (Zhu et al., 2012). Finally, these divergent results may be due to the specific racial/ethnic characteristics of the study population or the small sample size. Studies with a larger sample size are therefore required to confirm these findings. Further studies to confirm the U-shaped association between Alu methylation and BMI by measuring LINE-1 methylation and to understand the biological mechanisms underlying observed relationship are also required.

Collectively, the present study showed a novel U-shaped association between Alu methylation and BMI, suggesting that BMI-global DNA methylation relationship might play a convoluted role in etiology and pathogenesis of obesity as a hermetic dose response. In addition, the correlation could be a potential biomarker for the initial screening of other obesity-related disease. Furthermore, our results showed magnitude of obesity in general healthy population as Korean reproductive aged women.

\section{ACKNOWLEDGMENTS}

This research was supported by Basic Science Research Program through the National Research Foundation of Korea (NRF) funded by the Ministry of Science, ICT \& Future Planning (NRF-2012R1A1A1004307).

\section{REFERENCES}

Anderson, A.S., and Caswell, S. (2009). Obesity management-an opportunity for cancer prevention. Surgeon 7, 282-285.

Baccarelli, A., Wright, R., Bollati, V., Litonjua, A., Zanobetti, A., Tarantini, L., Sparrow, D., Vokonas, P., and Schwartz, J. (2010). Ischemic heart disease and stroke in relation to blood DNA methylation. Epidemiology. 21, 819-828.

Bernstein, B.E., Meissner, A., and Lander, E.S. (2007). The mammalian epigenome. Cell 128, 669-681.

Berrington de Gonzalez, A., Hartge, P., Cerhan, J.R., Flint, A.J., Hannan, L., Maclnnis, R.J., Moore, S.C., Tobias, G.S., AntonCulver, H., Freeman, L.B., et al. (2010). Body-mass index and mortality among 1.46 million white adults. N. Engl. J. Med. 363, 2211-2219.

Bollati, V., Baccarelli, A., Hou, L., Bonzini, M., Fustinoni, S., Cavallo, D., Byun, H.M., Jiang, J., Marinelli, B., Pesatori, A.C., et al. (2007). Changes in DNA methylation patterns in subjects exposed to low-dose benzene. Cancer Res. 67, 876-880.
Calabrese, E.J. (2010). Hormesis is central to toxicology, pharmacology and risk assessment. Hum. Exp. Toxicol. 29, 249-261.

Carless, M.A., Kulkarni, H., Kos, M.Z., Charlesworth, J., Peralta, J.M., Goring, H.H., Curran, J.E., Almasy, L., Dyer, T.D., Comuzzie, A.G., et al. (2013). Genetic effects on DNA methylation and its potential relevance for obesity in Mexican Americans. PLoS One 8, e73950

Danaei, G., Ding, E.L., Mozaffarian, D., Taylor, B., Rehm, J., Murray, C.J., and Ezzati, M. (2009). The preventable causes of death in the United States: comparative risk assessment of dietary, lifestyle, and metabolic risk factors. PLoS Med. 6, e1000058.

Deininger, P.L., and Batzer M.A. (1999). Alu repeats and human disease. Mol. Genet. Metab. 67, 183-193.

Esteller, M., Corn, P.G., Baylin, S.B., and Herman, J.G. (2001). A gene hypermethylation profile of human cancer. Cancer Res. 61 3225-3229.

Feinberg, A.P., Irizarry, R.A., Fradin, D., Aryee, M.J., Murakami, P., Aspelund, T., Eiriksdottir, G., Harris, T.B., Launer, L., Gudnason, V., et al. (2010). Personalized epigenomic signatures that are stable over time and covary with body mass index. Sci. Transl. Med. 2, 49-67.

Foley, D.L., Craig, J.M., Morley, R., Olsson, C.J., Dwyer, T., Smith, K., and Saffery, R. (2009). Prospects for epigenetic epidemiology. Am. J. Epidemiol. 169, 389-400.

Fujiki, K., Kano, F., Shiota, K., and Murata, M. (2009). Expression of the peroxisome proliferator activated receptor $\gamma$ gene is repressed by DNA methylation in visceral adipose tissue of mouse models of diabetes. BMC Biol. 7, 38.

Heyn, H., and Esteller, M. (2012). DNA methylation profiling in the clinic: applications and challenges. Nat. Rev. Genet. 13, 679692

Hsiung, D., Marsit, C., Houseman, E., Eddy, K., Furniss, C., McClean, M., and Kelsey, K.T. (2007). Global DNA methylation level in whole blood as a biomarker in head and neck squamous cell carcinoma. Cancer Epidemiol. Biomarkers Prev. 16, 108114

Kamei, Y., Suganami, T., Ehara, T., Kanai, S., Hayashi, K., Yamamoto, Y., Miura, S., Ezaki, O., Okano, M., and Ogawa, Y. (2010) Increased expression of DNA methyltransferase $3 a$ in obese adipose tissue: studies with transgenic mice. Obesity 18, 314-321.

Kheirandish-Gozal, L., Khalyfa, A., Gozal, D., Bhattacharjee, R., and Wang, Y. (2013). Endothelial dysfunction in children with obstructive sleep apnea is associated with epigenetic changes in the eNOS gene. Chest 143, 971-977.

Kim, K.Y., Kim, D.S., Lee, S.K., Lee, I.K., Kang, J.H., Chang, Y.S., Jacobs, D.R., Steffes, M., and Lee, D.H. (2009). Association of low-dose exposure to persistent organic pollutants with global DNA hypomethylation in healthy Koreans. Environ. Health Perspect. 118, 370-374.

Kim, J., Bhattacharjee, R., Khalyfa, A., Kheirandish-Gozal, L., Capdevila, O.S., Wang, Y., and Gozal, D. (2012). DNA methylation in inflammatory genes among children with obstructive sleep apnea. Am. J. Respir. Crit. Care Med. 185, 330-338.

Lin, J.D., Lin, P.Y., Chen, L.M., Fang, W.H., Lin, L.P., and Loh, C.H. (2010). Serum gutamic-oxaloacetic transaminase (GOT) and glutamic-pyruvic transaminase (GPT) levels in children and adolescents with intellectual disabilities. Res. Dev. Disabil. 31, 172177.

Low, S., Chin, M.C., Ma, S., Heng, D., and Deurenberg-Yap, M. (2009). Rationale for redifining obesity in Asians. Ann. Acad. Med. Singapore 38, 66-69.

Milagro, F.I., Gomez-Abellan, P., Campion, J., Martinez, J.A., Ordovas, J.M., and Garaulet, M. (2012). CLOCK, PER2 and BMAL1 DNA methylation: association with obesity and metabolic syndrome characteristics and monounsaturated fat intake. Chronobiol. Int. 29, 1180-1194.

Ozanne, S.E., and Constancia, M. (2007). Mechanisms of disease: the developmental origins of disease and the role of the epigenotype. Nat. Clin. Pract. Endocrinol. Metab. 3, 539-546.

Perng, W., Mora-Plazas, M., Marin, C., Rozek, L.S., Baylin, A., and Villamor, E. (2013). A prospective study of LINE-1 DNA methylation and development of adiposity in school-age children. PLoS One 8, e62587.

Peters, I., Vaske, B., Albrecht, K., Kuczyk, M.A., Jonas, U., and Serth, J. (2007). Adiposity and age are statistically related to enhanced RASSF1A tumor suppressor gene promoter methylation 
in normal autopsy kidney tissue. Cancer Epidemiol. Biomarkers Prev. 16, 2526-2532.

Piyathilake, C., Badiga, S., Johanning, G., Alvarez, R., and Patridge, E. (2011). Predictors and health consequences of epigenetic changes associated with excess bodyweight in women of childbearing age. Cancer Epidemiol. Biomarkers Prev. 20, 719.

Ramkumar, N., Cheung, A.K., Pappas, L.M., Roberts, W.L., and Beddhu, S. (2004). Association of obesity with inflammation in chronic kidney disease: a cross-sectional disease. J. Ren. Nutr. 14, 201-207.

Regitz-Zagrosek, V., Lehmkuhl, E., and Mahmoodzadeh, S. (2007). Gender aspects of the role of the metabolic syndrome as a risk factor for cardiovascular disease. Gend Med. 4, S162-177.

Renehan, A.G., Tyson, M., Egger, M., Heller, R.F., and Zwahlen, M. (2008). Body-mass index and incidence of cancer: a systematic review and meta-analysis of prospective observational studies. Lancet 371, 569-578.

Rodenhister, D., and Mann, M. (2006). Epigenetics and human disease: translating basic biology into clinical application. CMAJ 174, 341-348.

Ryan, D.H., and Braverman-Panza, J. (2014). Obesity in women. J. Fam. Pract. 63, S15-20.

Stenvinkel, P., Karimi, M., Johansson, S., Axelsson, J.. Suliman, M., Lindholm, B. Heimbürger, O., Barany, P., Alvestrand, A. Nordfors, L., et al. (2007). Impact of inflammation on epigenetic DNA methylation-a novel risk factor for cardiovascular disease? J. Int. Med. 261, 488-499.

Sull, J.W., Yun, J.E., Lee, S.Y., Ohrr, H., Jee, S.H., Gualler, E., and Samet, J.M. (2009). Body mass index and serum aminotransferase levels in Korean men and women. J. Clin. Gastroenterol. 43, 869-875.

Talens, R.P., Boomsma, D.I., Tobi, E.W., Kremer, D., Jukema, J.W., Willemsen, G., Putter, H., Slagboom, P.E., and Heijmans, B.T. (2010). Variation, patterns, and temporal stability of DNA methylation: considerations for epigenetic epidemiology. FASEB J. 24 3135-3144

Terry, M.B., Delgado-Cruzatak, L., Vin-Raviv, N., Wu, H.C., and Santella, R.M. (2011). DNA methylation in white blood cells: association with risk factors in epidemiologic studies. Epigenetics 6 , 828-837.

Vaiserman, A.M. (2011). Hormesis and epigenetics: Is there a link? Aging Res. Rev. 10, 413-421.

van Driel, L.M., Eijkemans, M.J., de Jonge, R., de Vries, J.H., van Meurs, J.B., Steegers, E.A., and Steegers-Theunissen, R.P. (2009). BMI is an important determinant of methylation biomarkers in blood of women of reproductive ages. J. Nutr. 139, 2315-2321.

Veronelli, A., Laneri, M., Ranieri, R., Koprivec, D., Vardaro, D., Paganelli, M., Folli, F., and Pontiroli, A.E. (2004). White blood cells in obesity and diabetes: effects of weight loss and normali- zation in obesity and diabetes: effects of weight loss and normalization of glucose metabolism. Diabetes Care 27, 2501-2502.

Wang, X., Zhu, H., Snieder, H., Su, S., Munn, D., Harshfield, G., Maria, B., Dong, Y., Treiber, F., Gutin, B., et al. (2010). Obesity related methylation changes in DNA of peripheral blood leukocytes. BMC Med. 8, 87.

Weisenberger, D.J., Campan, M., Long, T.I., Kim, M., Woods, C., Fiala, E., Ehrlich, M., and Laird, P.W. (2005). Analysis of repetitive element DNA methylation by MethyLight. Nucleic Acids Res 33, 6823-6836.

Whitlock, G., Lewington, S., Sherliker, P., Clarke, R., Emberson, J., Halsey, J., Qizilbash, N., Collins, R., and Peto, R. (2009). Bodymass index and cause-specific mortality in 900000 adults: collaborative analyses of 57 prospective studies. Lancet 373, 10831096.

Wolin, K.Y., Carson, K., and Colditz, G.A. (2010). Obesity and cancer. Oncologist 15, 556-565

Yang, A.S., Estecio, M.R.H., Doshi, K., Kondo, Y., Tajara, E.H., and Issa, J.P. (2004). A simple method for estimating global DNA methylation using bisulfite PCR of repetitive DNA elements. Nucleic Acids Res. 32, e38.

Yang, H.H., Hu, N., Wang, C., Ding, T., and Dunn, B.K. (2010). Influence of genetic background and tissue types on global DNA methylation patterns. PLoS One 5, e9355.

Ye, C., Shrubsole, M.J., Cai, Q., Ness, R., Grady, W.M., Smalley, W. Cai, H., Washington, K., and Zheng, W. (2006). Promoter methylation status of the MGMT, hMLH1, and CDKN2A/p16 genes in non-neoplastic mucosa of patients with and without colorectal adenomas. Oncol. Rep. 16, 429-435.

Young, T., Palta, M., Dempsey, J., Skatrud, J., Weber, S., and Badr, S. (1993). The occurrence of sleep-disordered breathing among middle-aged adults. N. Engl. J. Med. 328, 1230-1235.

Zhang, F.F., Cardarelli, R., Carroll, J., Fulda, K.G., Kaur, M., Gonzalez, K., Vishwanatha, J.K., Santella, R.M., and Morabia, A (2011a). Significant difference in global genomic methylation by gender and race/ethnicity in peripheral blood. Epigenetics 6, 623-629.

Zhang, F.F., Santella, R.M., Wolff, M., Kappil, M.A., Markowitz, S.B., and Morabia, A. (2011b). White blood cell global methylation and IL-6 promoter methylation in association with diet and lifestyle risk factors in a cancer-free population. Epigenetics 6, 606-614.

Zheng, W., McLerran, D.F., Rolland, B., Zhang, X., Inoue, M., Matsio, K., He, J., Gupta, P.C. Ramadas, K., Tsugane, S., et al (2011). Association between body-mass index and risk of death in more than 1 million Asians. N. Engl. J. Med. 364, 719-729.

Zhu, Z.Z., Hou, L., Bollati, V., Tarantini, L., Marinelli, B., Cantone, L., Yang, A.S., Vokonas, P., Lissowska, J., Fustinoni, S., et al. (2012). Predictors of global methylation levels in blood DNA of healthy subjects: a combined analysis. Int. J. Epidemiol. 41, 126-139. 